\title{
A Systematic Review of Grounded Theory Methodology: Re-Grounding in Weber
}

\author{
Yuting Zhuang \\ Shanghai University of Accounting and Finance \\ Zhijuan Song
Yunnan Minzu University
}

Grounded theory is considered one of the most rigorous methodologies in qualitative research. Debate on its philosophical paradigm has trended toward endless over the past 50 years, as it was not clarified in its first canon. Scholars from multiple disciplines and philosophical backgrounds have contributed throughout its development, necessitating a comparison of the evolving dynamics of philosophies in the key grounded theory methodological schools. This article provides a systematic comparison at both substantive and formal levels, analyzing the philosophical approaches and methodological designs of Glaser, Strauss and Corbin, and Charmaz. The philosophical paradigms chosen by these three key schools and how they are perceived by researchers who adopted grounded theory methodology are presented. Formal grounded theory methodological design is limited in comparison to substantive grounded theory methodology. A novel Weberian approach is proposed to re-ground formal grounded theory methodology; contributing to initial grounded theory methodological design.

Keywords: Grounded Theory Methodology, Philosophy of Science, Comparative Analysis, Formal Theory

\section{INTRODUCTION}

Grounded theory methodology originated in sociology and nursing, and is well-explored in medicine, information science, and recently business and education research. Although grounded theory methodology is one of the most popular qualitative research methodologies (along with meta-theory, qualitative synthesis, and systematic theory), there is probably more confusion about what grounded theory methodology is, and what it is not, due to its complex nature. The three prevalent approaches (as described by Glaser, Strauss and Corbin, and Charmaz) should not be compared solely on the level of difficulty encountered in implementing their procedures, but more significantly on their ontological impacts on the methodological design and its competence to cope with the phenomena relevant to the scope of the research question(s).

Many methods and methodologies have the potential to develop social theories; however, no other methodology expresses its aim in theory development as boldly as grounded theory methodology (GTM). GTM is about "the discovery of theory from data systematically obtained from social research" (Glaser \& Strauss, 1967, p. 2). Glaser updated the definition to take a more generalized approach: 
GT (Grounded Theory) is simply the discovery of emerging patterns in data. Everything has patterns. Everybody engages in GT every day because it's a very simple human process to figure out patterns and to act in response to those patterns. GT is the generation of theories from data. GT goes on every day in everybody's lives: conceptualizing patterns and acting in terms of them. (Walsh, Holton, Bailyn, Fernández, Levina, \& Glaser, 2015, p. 593)

Based on comparative analysis, there are two types of (grounded) theory generated from an empirical field: substantive (grounded) theory (SGT) and formal (grounded) theory (FGT). SGT develops from substantive areas of sociological inquiry, while formal theory (FGT) is generated from formal conceptual areas of sociological inquiry (Glaser \& Strauss, 1967, p. 32). Theory development was a fashion in the hard sciences before its popularity in the social sciences. Some fundamental assumptions about theories still show the strong influence of their initial fields.

There is a close relationship between management research, GTM, and qualitative data analysis software, with a strong tendency of software adoption in GTM application in management journal articles (ProQuest, 2013). The high percentage of management research with GTM adopting data analysis software indicates a quantitative orientation in current management research. Quantitative researchers have become accustomed to engaging software in data analysis to improve overall efficiency.

From 1990 to 2019, the three dominant software packages for qualitative research coding cited in the ProQuest database were ATLAS (commercialized in 1993) (ATLAS.ti, 2014), NUDIST (predecessor of NVivo) since 1981, and NVivo since 1990 (QSR, 2014). The majority of researchers engaged in qualitative data analysis (QDA) software development applied GTM for initial product testing. According to ProQuest (2019), $80 \%$ to $90 \%$ of QDA applying GTM were from management, and management research accounted for between $40 \%$ and $50 \%$ of all GTM applications since 1990. The relationship among GTM and management and QDA software indicates that management research is a key research area in GTM, and management research leads the application of software in GTM research.

Based on the increasing adoption of GTM by management researchers, arguments have arisen regarding how it should be conducted. The time has arrived for management scholars to provide a more defined direction for the future use of GTM in their research. Some would argue that GTM cannot continue to be practiced as a free-for-all methodology in management research without risking becoming irrelevant (Jones \& Noble, 2007). It appears that the GTM techniques associated with data collection and analysis are popular among management scholars; however, studies embracing a holistic approach to the methodology itself remain limited (Loonam, 2013).

Åge (2011, p. 1601) indicated that "the founders of particular scientific methodologies, including GTM, often fail to explore and explain the fundamental philosophical basis of their particular methodologies - even when the theoretical and conceptual principles of that methodology are ostensibly being presented." Gustavsson (1998) further noted that GTM had been subjected to criticism from both subjectivists and objectivists.

Thorough GTM research in management is quite rare, and mostly involves minimal discussion of the philosophical backgrounds of GTM schools. For example, an analysis of the 10 management journals included in the 45 Financial Times Top Journals in 2012 (Financial Times, 2012), identified 31 articles employing GTM, but only three of these discussed the philosophical background of GTM (Hallier \& Forbes, 2004; Shah \& Corley, 2006; Suddaby, 2006).

\section{Comparing Substantive Grounded Theory Methodological Schools}

In the historical philosophical discussion of GTM, there have been three waves. In the earliest stage of GTM development (see Figure 1), the debate was based on GTM and other qualitative research methods and how GTM follows the positivist tradition in research logic, which is also known as classic GTM when Glaser and Strauss (1967) initiated the original GTM (Chametzky, 2013). 


\section{FIGURE 1 \\ BRIEF HISTORY OF GROUNDED THEORY RESEARCH}

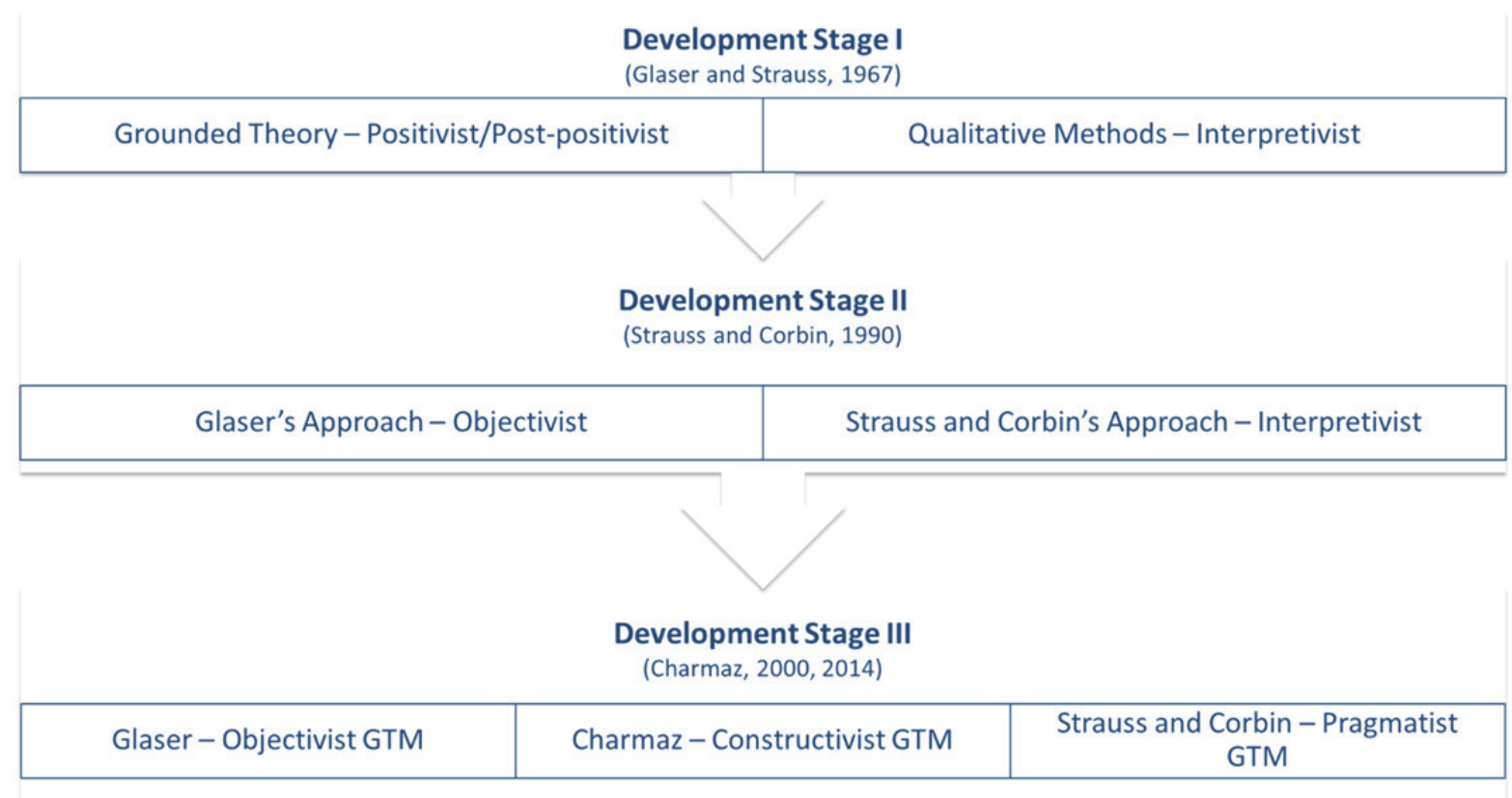

The notion that GTM belongs to a positivist or post-positivist tradition arose during that time. The first development stage, when Strauss and Corbin (1990) published Basics of Qualitative Research: Grounded Theory Procedures and Techniques, departs from Glaser and the classic approach of GTM. Glaser considered himself more aligned with the original purpose of GTM, while Strauss and Corbin's GTM development tends to be more aligned with a standard pragmatist procedure, rather than systematic thinking, resulting in Glaser's critique that Strauss had betrayed their original purpose for GTM and that he was attempting to force theories to emerge through a standard procedure (Glaser, 1992; Seldén, 2005).

Most of the researchers following Glaser are active in Grounded Theory Review, a journal initiated by Glaser and a channel that promotes Glaser's approach to GTM. Key followers of Strauss include Corbin (2009; Corbin \& Strauss, 1990, 2008, 2015; Strauss \& Corbin, 1990; 1994, 1997, 1998); Clarke (2003, 2005, 2007, 2008; Clarke \& Star, 2007); Denzin (2007; Denzin \& Lincoln, 1994); Kearney (1998a, 1998b, 1999, 2007); Locke (2001, 2007); Star (1999, 2007); and German sociologists Strübing (2007), Soeffner, Grathoff, Riemann, Hildenbrand, and Hoffman-Riem (Clarke, 2008).

In the current discussion of GTM schools, a relatively new stream of GTM led by Charmaz (2000, 2004, 2006, 2008, 2014) and Bryant (2006; Bryant \& Charmaz, 2007) has positioned a revised approach to GTM within the constructivist paradigm developed based on Strauss (Clarke, 2008; Denzin, 2007; Reynolds \& Herman-Kinney, 2003). Charmaz emphasized a constructivist version of GTM which indicates that the researcher's role in GTM is not only the analysis of data but also playing a more active role as a participant and contributor to the theories that emerge from the application of GTM. Glaser strongly argued against Charmaz's constructivist approach, stating point-blank that "grounded theory is not constructivist" (Glaser, 2012, p. 28; 1998). Corbin and Strauss are more open to constructivism and seek its validity (Corbin \& Strauss, 2008, p. 9). Nevertheless, Charmaz's approach has won the favor of GTM researchers as it is easier to manage and less critical of the position of constructivists. Thus, three schools of GTM have formed. The following two sections explore the philosophical approaches and research designs of the GTM schools to evaluate their internal methodological consistency.

Glaser (1998, p. 41) commented, "Grounded theory is a general method and it is only a methodological option... to try to wed it to another methodology dilutes and complexifies its simple inductive approach... it works with any data, because all is data for generating theory". Wedding it to 
phenomenology, ethnography, concepts of hegemony and even positivism distorts true emergence for theory generation. However, the discussion about which philosophical paradigm GTM belongs to continues unabated.

Researchers from different philosophical paradigms seek to determine whether GTM aligns or conflicts with their ontologies. How individual researchers perceive GTM differs widely (see Figure 2). Since Charmaz's school is more consistent with constructivism, the comparison focuses on the differences between the approaches of Glaser and Strauss and that of Corbin. To Åge (2011), Glaserian GTM could be related to hermeneutics (constructivism) and pragmatism as well as the positivist tradition. Charmaz $(2000,2006,2014)$ and Hallier and Forbes (2004) consider the old schools of GTM to be positivist, following the tradition of GTM as established by Strauss and Corbin $(1990,1998)$ and Glaser $(1978,1992,1998,2001,2003)$. Positivism, based on the work of Comte, focuses on science as a product - as a linguistic or numerical set of statements, a concern with axiomatization, and an insistence on at least some of these statements being testable. Positivists believe that science is markedly cumulative, predominantly transcultural, and rests on specific results. They believe that science contains theories or research traditions that are largely commensurable and sometimes incorporate new ideas that are discontinuous from old ones. They believe that science involves the idea of the unity of science, and that science is nature and nature is science.

\section{FIGURE 2}

\section{PHILOSOPHICAL DISCUSSION OF GROUNDED THEORY METHODOLOGY}

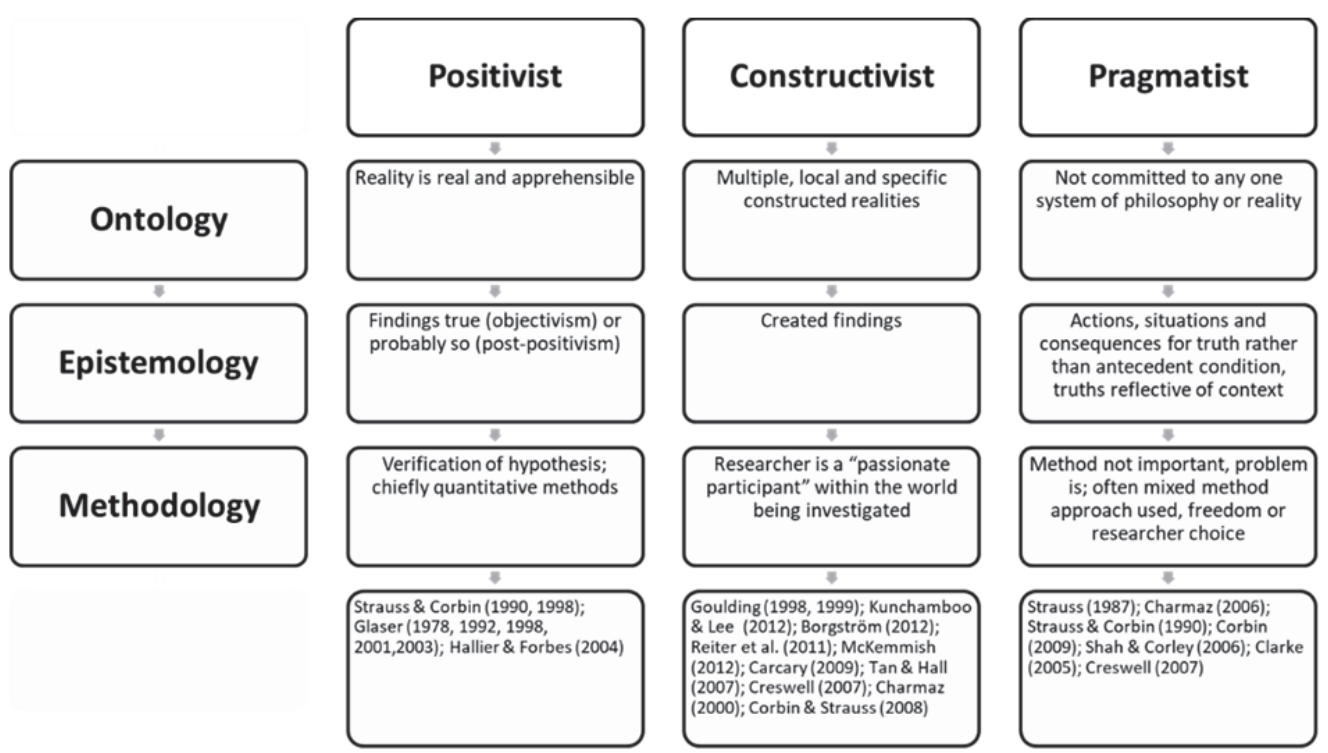

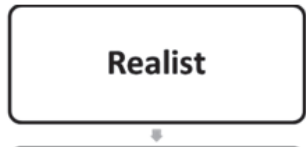
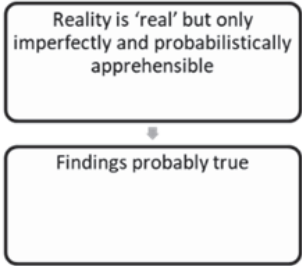

Triangulation, interpretation of research issues by qualitative and quantitative methods

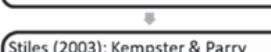
(2011); Locke (2001)

Source: Figure created based on the philosophy of research structure in Guba and Lincoln (1994) and McNeill (2007)

In opposition to positivists, interpretive social scientists hold a variety of opinions that conflict with each other. Ponterotto (2005), Omar et al. (2012), Yeadon-Lee (2013), Brown (1995), Goulding (1998), Suddaby (2006), and Lowenberg (1993) consider GTM as belonging to the larger body of interpretivism. Goulding (1998, 1999), Kunchamboo and Lee (2012), Borgström (2012), Reiter et al. (2011), McKemmish et al. (2012), Carcary (2009), Tan and Hall (2007), Charmaz (2000), Corbin and Strauss (2008), and Creswell (2007) comment that GTM should or could be aligned with constructivism. Constructivists perceive multiple realities and mutual construction of data through social interaction. They assume that the researcher constructs categories and views the representation of data as problematic, relativistic, situational, and partial. Their values, priorities, positions, and actions affect the resulting views. 
Strauss (1987), Strauss and Corbin (1990), Corbin (2009), Shah and Corley (2006), Clarke (2005), and Creswell (2007) position GTM in the philosophical school of pragmatism or post-modernism (Flick, 2018). The pragmatist school was formed by the philosopher William James (McDermid, 2006), who claimed that an ideology or proposition is true if it works satisfactorily, a proposition is to be found in the practical consequences of accepting it, and unpractical ideas are to be rejected.

Stiles (2003) places GTM under realism, while Kempster and Parry (2011) argue that it belongs to critical realism. Locke (2001) considers it to be objective realism. Although philosophical discussions can become quite convoluted, there is evidence that more qualitative and quantitative researchers are seeking to validate the use of GTM in their research and are attempting to find a way to match GTM with their philosophical preferences.

Is it possible for GTM to be paradigm free? What is the philosophy behind the design of GTM? The early work of Glaser and Strauss (1967) was positioned among the positivist paradigm, or more accurately, they did not distinguish themselves from the positivist paradigm in order to win favor among quantitative researchers, and GTM was claimed to be one of the most rigorous qualitative methodologies that could meet comparable level of validity and reliability as quantitative methods. Therefore, the general understanding of classic GTM is under positivist paradigm, rather than post-positivist paradigm which might be a more suitable position for qualitative research.

Charmaz (2014) examined the ontological preferences of Glaser and Strauss according to where they gained their qualifications, based on Corbin (2009, pp. 36-37), concluding that Glaser belongs to Columbia positivism, illustrated by Popper (1963, 1972, 1992); and Strauss to the Chicago heritage of symbolic interactionism (pragmatism) (Corbin \& Strauss, 2008). Symbolic interactionism by George Herbert Mead (Charon, 2004) holds that humans must be understood as both a social person and a thinking being. It is an important philosophical approach in American sociology, which derives from pragmatist school introduced by Dewey and Mead (Huber, 1973).

Due to such conflict, Glaser and Strauss departed due to their uncompromisable philosophical stands in the end. The philosophical differences influenced their general assumption of what is reality, what is data, how to deal with literature, the research procedure, data coding and interpretation. They see the world differently. As an emerging GTM theorist, Charmaz (2014) takes a constructivist approach. Microscoping GTM design aspects of Glaser's and Strauss's approaches provides insights into their design logic and hidden philosophies.

Table 1 below systematically compares the three key GTM approaches: Classic/Glaserian GTM, Straussian GTM, and Charmaz's GTM. The table illustrates how GTM approaches (apart from Charmaz) occupy multiple paradigms described by the theorists or interpreted by other researchers; and how ontological and epistemological positions can influence their methodological design. 


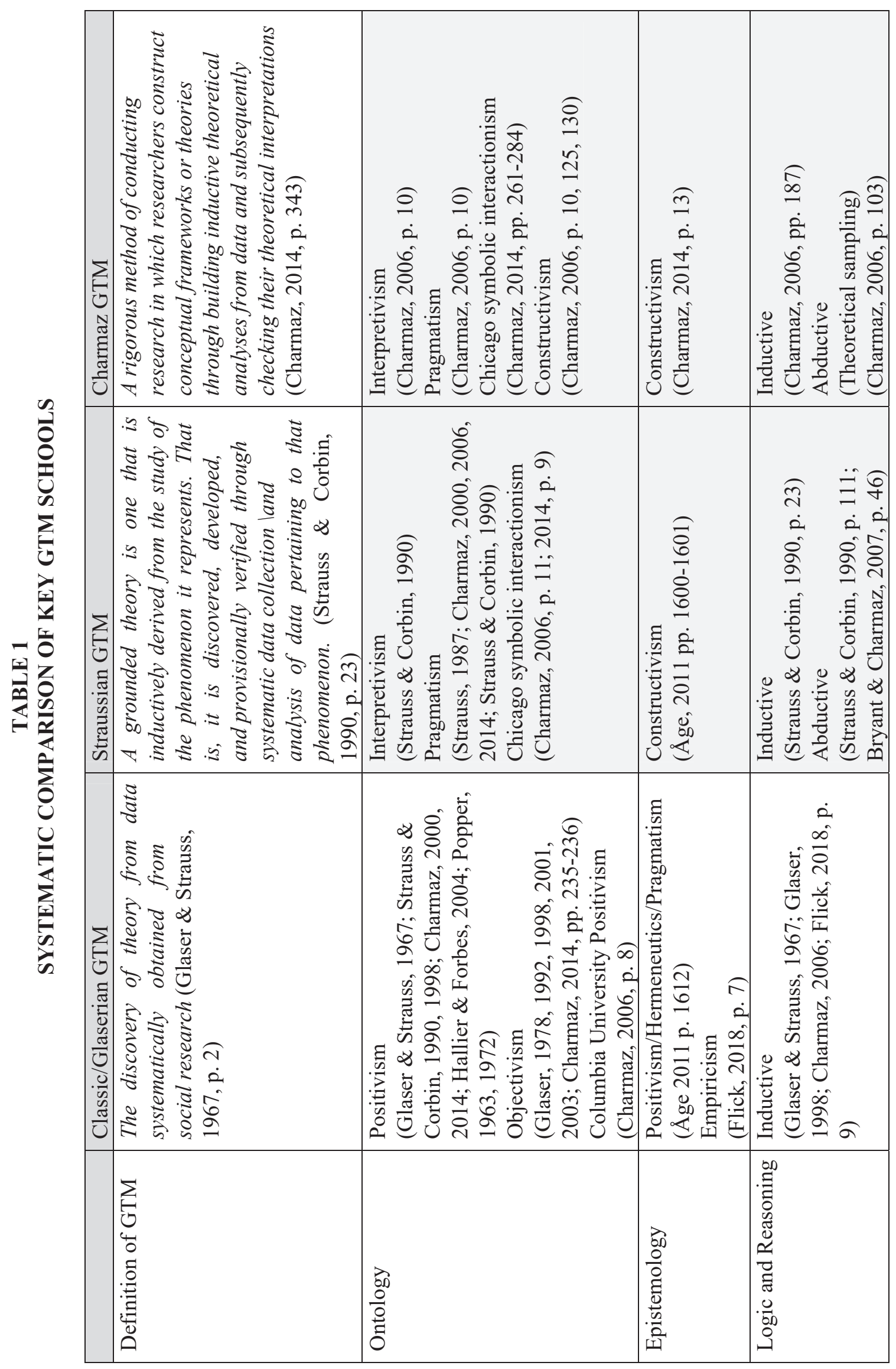

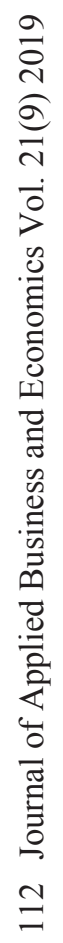




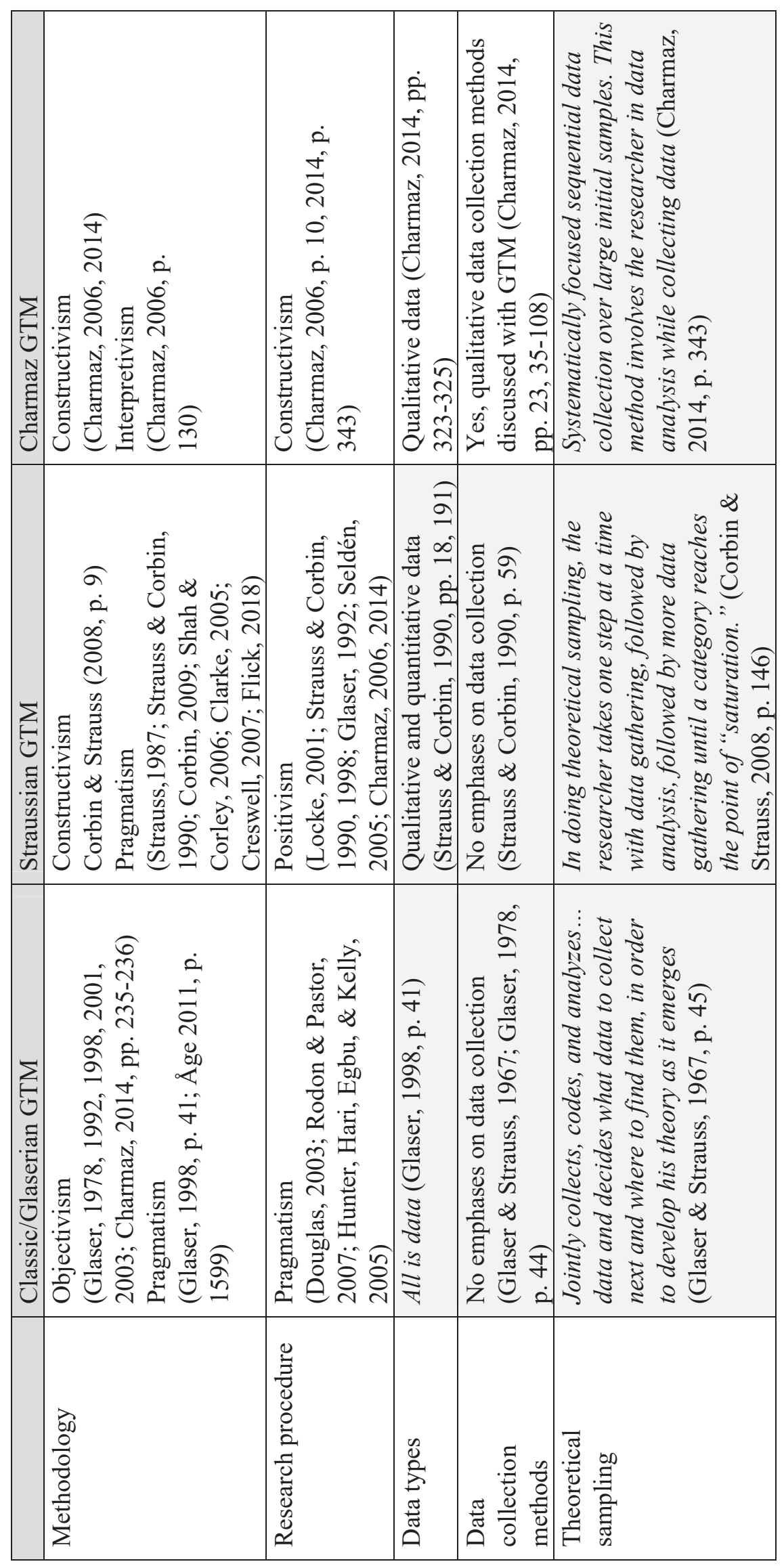

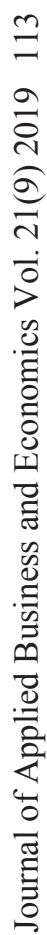




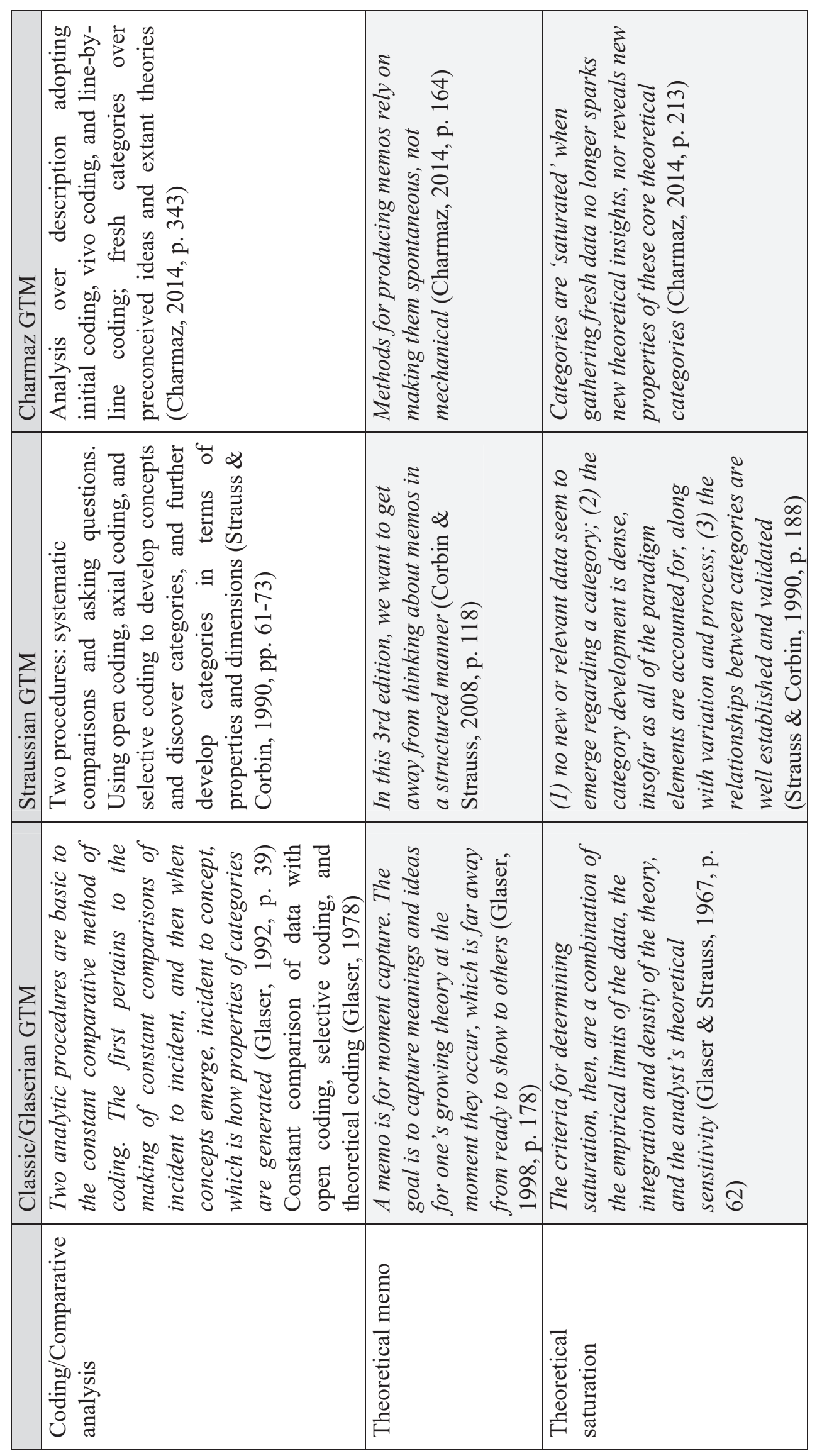

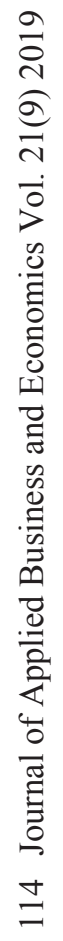




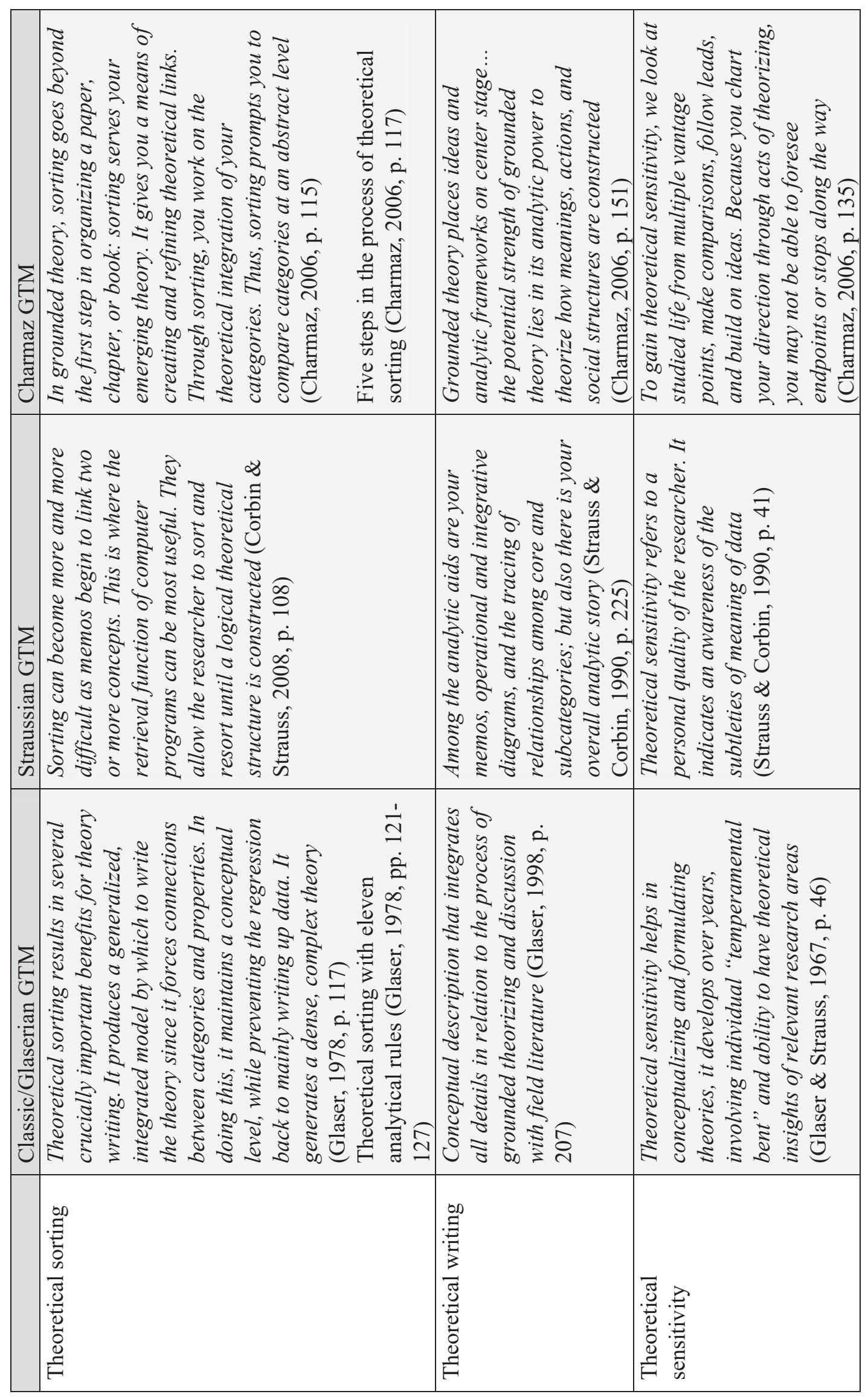

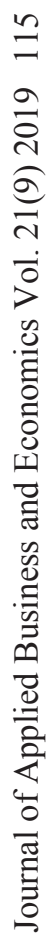




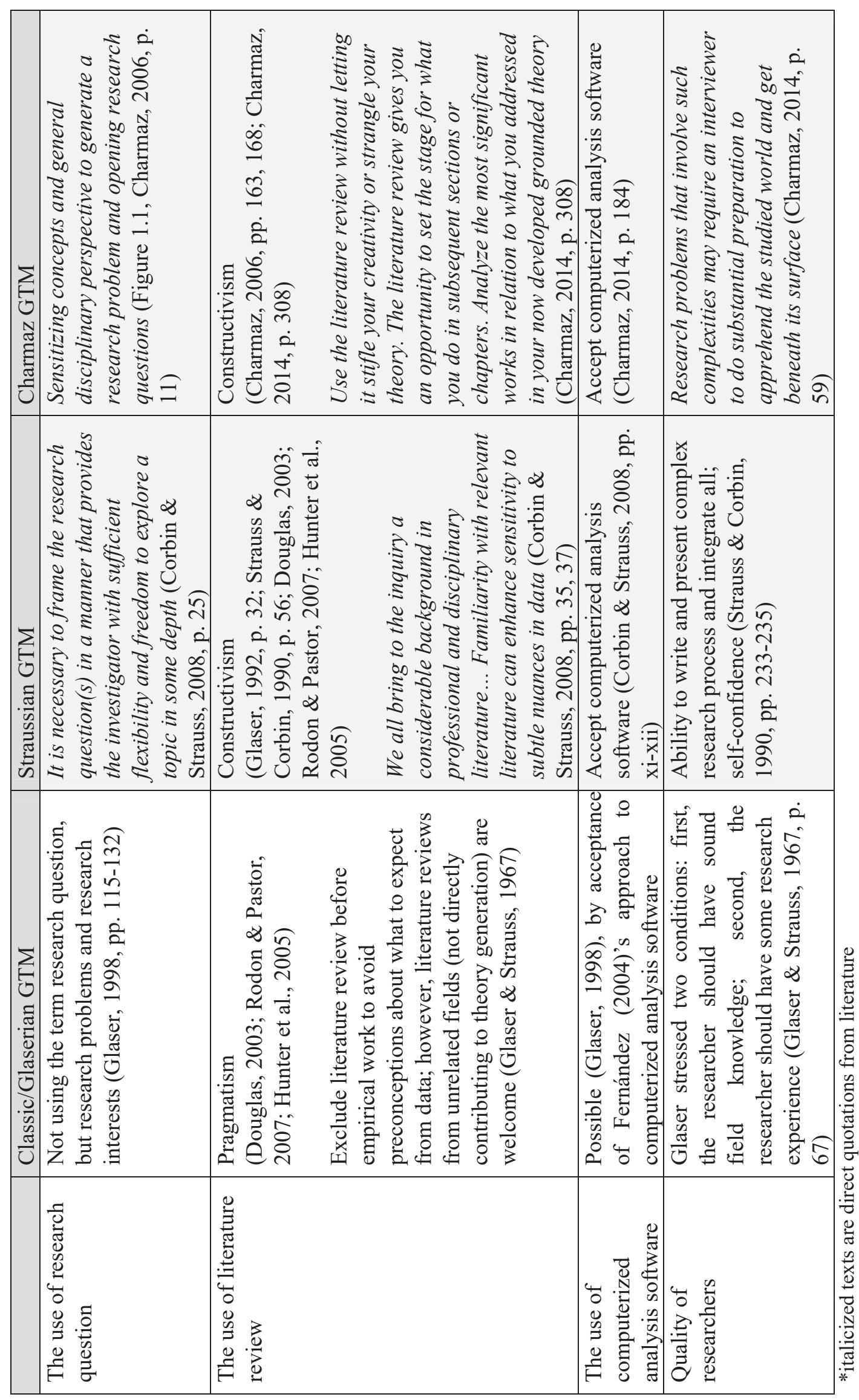

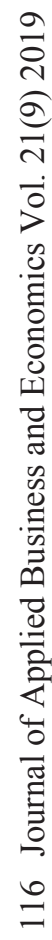


The comparison in Table 1 indicates some interesting patterns amongst the three key schools. The definitions of GTM reflect the theorists' philosophical positions, especially Glaserian and Charmaz's. The word "discovery" reflects positivists' understanding that social reality exists and is comprehensive, while Charmaz views GTM as a process of "constructing" theories, a position identical to that of constructivists. The Straussian definition is more focus on the procedure of GTM, rather than focusing on its philosophical paradigm. All three definitions reveal a systematic approach.

In terms of ontology and epistemology in Table 1, Strauss and Corbin's position is similar to Charmaz, apart from Charmaz's ontology has a strong tendency of constructivist position. In the later development of Straussian school, Corbin favors constructivism and become even closer to Charmaz (Strauss \& Corbin 1998, p.25). Åge (2011, p. 1601) considers the epistemology of Glaser to be pragmatist and that of Strauss and Corbin to be constructivist. Flick (2018, p. 7) argues that the epistemological approach of Glaser is rather empiricist, especially towards "all is data". Glaser commented that GTM is a perspective-based methodology and people's perspectives vary (Glaser, 2002).

Both Straussian and Charmaz's approaches engage abductive reasoning in addition to inductive reasoning. Bryant and Charmaz (2007, p. 46) argued that even Strauss seldom use the word "abduction"; however, there are strong characteristics of abductive reasoning in his writings with the impacts of Dewey, Peirce, Mead and Blumer. Abductive reasoning is a variety of inductive reasoning and is often described as "inference to the best explanation" to make or justify hypotheses (Stanford Encyclopedia of Philosophy, 2017); while inductive reasoning is based on evidence to come into a "probably truth" conclusion. The logic of abductive reasoning conflicts with the original design of GTM to avoid preconceptions during empirical work and data analysis.

There are some significant evolving paths in Glaserian and Straussian approaches. Glaser (1998, p.41) started to claim his pragmatism position; while Corbin and Strauss (2008, p.9) fell into the position of constructivism. Glaser (1998, p. 41) started to claim: "All is data". This evolves from their original design to focus more on qualitative data types. In the later phrase of Straussian led by Corbin, they become more flexible, such as the memoing procedure, with a very similar tendency to the recent development of Glaserian approach.

Interestingly, their philosophical positions misalign with the logic of their research procedures; however, there is clear rationale behind such misalignment, which also indicates differences between inductive and abductive reasoning. Taking a positivist/objectivist position, the discovery of theory is a process of finding (or discovering) something exists, the procedure thus is more likely to be iterative until the find the "probably truth" without preconceptions. Taking a pragmatist position with abductive reasoning is to use whatever is the most efficient method and process to predict a theory with practical implementation. The constructivist position of Charmaz is the only paradigm that consist with its research procedure.

The data types and data collection methods are similar between Glaserian and Straussian; which welcomes multiple data types in both qualitative and quantitative forms; while Charmaz encourages qualitative data and provides guidelines in employing qualitative data collection methods incorporating GTM. There are some crucial areas that are shared by the three schools as the general standards of GTM: constant comparison, systematic coding, theoretical sampling, theoretical memoing, theoretical saturation, theoretical sorting, theoretical writing, and theoretical sensitivity.

Glaserian is different from the rest two in the use of research question, the use of literature review, the use of computerized analysis software, and the discussion of the quality of researchers. Glaser (1998) considered research question is not appropriate for GTM, but research problems and interests. While, Straussian and Charmaz considered open research questions are suitable, which matches better with novice GTM researchers' previous experience in quantitative and qualitative methods. Pre-empirical work literature review is also banned by Glaser to avoid preconceptions; while Straussian consider it is beneficial to develop theoretical sensitivity (Corbin \& Strauss, 2008, pp. 35, 37); and Charmaz also holds positive attitude towards literature review pre-empirical research as long as creativity is not strangled (Charmaz, 2014, p. 308). Regarding computerized analysis software, Glaser (2003) stated that he likes to think that GTM involves complex, not so intuitive, procedural in conceptualizing patterns. He has come 
out in opposition to computer software and QDA's capability in GTM coding, despite his mathematics and sociology background. Glaser (1998, p. 185) commented there might be a possibility to code GTM with computer in the future, but not yet. Regarding quality of researchers, Glaser emphasizes more on the experience and knowledge of researchers; while Strauss and Corbin, and Charmaz focus on their research skills and preparation to handle the inner complexity in GTM.

\section{Comparing Formal Grounded Theory Methodological Approaches}

Glaser and Strauss (1965, pp. 280-282) divided social theories into two main categories: FGT and SGT. Grand theory is logico-deductive, systematic, leads to hypothesis testing, and is highly abstract. Substantive and formal grounded theories are both in the scope of middle range theory, which is data inductive, systematic, and has a certain level of abstraction and generalization (Glaser, 1968, p. 13, Merton, 1968). Merton (1968, p. 39), the developer of the middle-range theory concept in social theorizing to lead empirical research, stated: "It is intermediate to generate theories of social systems which are too remote from particular classes of social behavior, organization and change to account for what is observed and those detailed orderly descriptions of particulars that are not generalized at all".

Predictability and explanatory power of the theory are less stressed in GTM but are mentioned in Status Passage (Glaser \& Strauss, 1971, p. 176). Glaser and Strauss use "abstract" and "generalizability" mostly in relation to FGT, so it is likely that only FGT is comparable with social theories and theorizing methods, while SGT developed through GTM is quite like findings from other research methods, such as ethnography, phenomenology, or action research.

Within GTM, there are three dominant schools: Glaser's school, Strauss \& Corbin's school, and Charmaz's school. The following paragraphs will focus on an ongoing theoretical discussion of the three schools based on their GTM designs and philosophy and will then propose a formal GTM model.

In their first publication, Glaser and Strauss (1967, p. 79) mentioned that "substantive theory is a strategic link in the formulation and generation of grounded formal theory... It is most desirable, and usually necessary, to start the formal theory from a substantive one". There is some confusion between SGT and FGT in business studies, such as Malik (2013) who considered GTM as not aiming to develop substantive theories. Glaser $(1999$, p. 842) predicted: "in the future... there frequently will be poor grounded theory research, but it must be seen as developmental". The necessity of a formal GTM construct conflicts with the reality that not enough researchers are passionate about developing GTM. It restricts the quality of grounded theorizing. Current practices comparing substantive areas through modified comparative method are not efficient (Bryant \& Charmaz, 2007).

\section{The Nature of Formal GTM}

There are assumptions about formal GTM design. First, there are researchers who believe that generalizability should be a fundamental feature of FGT (Chametzky, 2013; Mjøset \& Clausen, 2007, p. 16; Bales \& Gee, 2012; Stebbins, 2006; Parker \& Roffey, 1997) and take the classic approach to theorizing. Mjøset and Clausen (2007) stated that such generalization should be built upon substantive typologies and formal mechanisms. Parker and Roffey (1997) considered that the generalizability mentioned in Glaser \& Strauss (1967) should apply to variation for conditions and broader conditions incorporated.

Second, grounded theories should be built up on a comparative analysis method (Glaser, 1968, p. 7; Glaser, 1992; Mjøset \& Clausen, 2007; Clarke, 2008). Clarke (2008) considered the comparative analysis method of Margaret Kearney, a key formal theorist, an "inconstant comparison".

The third assumption is the abstraction of conceptual systems (Mjøset \& Clausen, 2007; Wallis, 2014; Apprey, 2005, 2007). Wallis (2014) declares that the goal of formal GTM is to seek highly abstract categories that can fully represent the concepts within the conceptual systems. Apprey (2005) suggests that formal GTM can be used to combine multiple theories and so gain more meaning and insight in an area of study. It is unclear if that extra step supports the creation of improved conceptual systems. It is entirely possible that identifying all the abstractions can result in a conceptual system that is much larger and more complex than the subject conceptual system upon which it is based (Glaser, 2007a). Mjøset and 
Clausen's (2007, pp. 13-14) approach of formal GTM is the combination of SGT in the form of typologies and periodization with mechanisms and a third step systematic process analysis. Finally, there are theorists that believe transferability is another feature very close in concept to generalizability (Chametzky, 2013; Bakir \& Bakir, 2006).

Glaser and Strauss discussed the difficulties in developing a formal GTM construct as it must be based on current substantive GTM constructs to build a broader and higher abstraction methodological construct (Glaser, 2007a). Glaser published Doing Formal Grounded Theory: A Proposal in 2006 and commented that his design of formal GTM is neither developing coding strategies nor proposing a grand theory (such as in the natural sciences) but focusing on broadening the general application of core categories (of substantive theories) (Glaser, 2006).

\section{Formal GTM by Glaser, Strauss, and Charmaz}

Throughout the decades, there are only five studies that Glaser officially claimed to have generated FGTs: awareness context from Awareness of Dying (Glaser \& Strauss, 1965), Outsiders (Becker, 1963), Organizational Career (1968), Status Passage (Glaser \& Strauss, 1971), and the discovery of cautionary control (Gibson, 1997; Glaser, 1992, p. 99; Glaser, 2007b, p. 3; Bryant \& Charmaz, 2007, pp. 98-100). Interestingly, three of these pieces of research are by Glaser and Strauss, and the identification of the five FGTs even predates Glaser's (2006) proposal in formal GTM construct. It seems as if Glaser and Strauss were urged to claim their territory without "legitimacy" based on a general understanding of what is a "formal" or "general" theory (Glaser \& Strauss, 1965).

If formal GTM is part of GTM, its methodological design should be based on substantive GTM rather than other qualitative methods that have already forged their way in theorizing. Glaser and Strauss were much less confident about the status of their analysis in Awareness of Dying (which Glaser claimed to be FGT), "if one wishes to develop a systematic formal (or general) theory of awareness context, he must analyze data from many substantive areas" (Glaser \& Strauss, 1965, p. 276). The Organizational Career is even worse, as it is merely a grand literature review with a minimal (close to no) analysis of literature put into chapters.

Charmaz considered that it is the time to codify formal GTM procedures in response to the original call from Glaser and Strauss (1967, p. 80) that "more specific procedures await the time when enough sociologists will have generated FGTs that their procedures can be codified", disregarding the fact that Glaser published the formal GTM in 2006 with the same title (Bryant \& Charmaz, 2007). She was planning for a new publication in "Doing Formal Grounded Theory". Both Glaser and Charmaz believe the formal grounded theorizing method is based on codifying substantive GTM projects.

\section{Formal GTM by Other Researchers}

Apart from Glaser and Charmaz, there are three key contributors to formal GTM development: Margaret Kearney (1998a, 1998b, 1999, 2007) in nursing, Isabel Walsh (2015) in information science, and Steven Wallis (2014) in sociology. Kearney is one of the very early developers of the formal GTM construct (Clarke, 2008; Bales \& Gee, 2012). She applies substantive GTM criteria to evaluate formal GTM, adopting a systematic synthesis approach in the comparisons of 10 "self-identified" grounded pieces of research, which had been coded separately first. Kearney's formal GTM construct has three steps: theoretical coding, comparison across substantive theories, and the emergence of FGTs (Kearney, 1998a, 1998b). The condition of Kearney's research is that substantive grounded theories in the relevant area are developed; thus, her approach cannot work as well in a field without any grounded theories.

Walsh's (2015) design, starting with a clarification of methodological terms, traced GTM research back to its origin - Paul Lazarsfeld and his inductive quantitative methodology (Christiansen, 2008, cited by Walsh, 2015). Both Walsh (2015) and Wallis (2014) integrated meta-theory design into GTM with developed conceptual system and dimensions analysis. Walsh took the logical step to mix GTM design with quantitative data analysis to form an exploratory formal GTM construct with rupture theory (concepts and propositions) at the centre with contributions from three directions: qualitative data, quantitative data, and literature review. Walsh takes a theoretical triangulation (Denzin, 2006) led by 
Glaser's classic GTM and "all is data" principle to combine the three main schools of GTM - Glaser, Strauss, and Charmaz - into a meta-theory development system.

Walsh's (2015; Walsh et al., 2015) design gives the research insights into how to combine qualitative and quantitative data to develop FGT to complement the formal GTM design in this paper from a different approach. The philosophical discussion of Walsh is based on the existing GTM approaches with contributions from relevant quantitative methodology, while the discussion in this paper is rooted in the world system of philosophy discussion and the application of Weber's sociology to reconstruct classic GTM to a GTM applying Weberian sociological principles. Walsh's construct with multiple philosophical approaches is more suitable for team research project with each researcher taking a different philosophical position. It is less likely a researcher can have multiple philosophical approaches as philosophical status is less likely to evolve in a short period of time; whereas, the methodological design of this paper provides a continuous construct for individual research; yet possible for researchers that agree on the general assumptions of Weberian (Neo-Kantian) approach, including idealism and interpretivism. The difficulty in developing a formal GTM construct is still quite explicit. Some complex concepts need to be fragmented into multiple simpler concepts before being combined into categories. Moreover, it is unclear whether that extra step supports the creation of improved conceptual systems (Wallis, 2014). It is easy to find oneself with a conceptual system that is a collection of ideas rather than a set of interrelated propositions. Thus, one may end up with a construct that is hardly a theory (or a system) at all. The technical problems include: How can we systematically compare substantive theories in GTM research? Does the comparison happen at the substantive theory level or the level of core category? What is the quality of SGTs in comparison to other theories emerged from a substantive area through other methodologies and methods?

\section{Use of Literature in Grounded Theory Methodology}

The use of literature is considered one of the most challenging components of GTM design, partially due to internal conflicts and inconsistency in the use of literature in GTM by its originators, especially the use of literature between substantive and formal GTM.

The use of literature is at the center of debates between Glaser's and Strauss's schools of GTM. Glaser never compromises from the original design of the purpose and usage of literature in GTM research to exclude literature review before empirical work to avoid preconceptions about what to expect from data. On the other hand, Strauss deviates from the original GTM design to take a more constructive approach and welcome all literature use before empirical work (Glaser, 1992, p. 32; Strauss \& Corbin, 1990, p. 56; Douglas, 2003; Rodon \& Pastor, 2007; Hunter et al., 2005).

In general, Strauss and Corbin's (1990) approach to the positioning of the literature review will win favor with many social researchers and is closer to the logic of other methodological designs. They divided literature into technical and nontechnical literature. The technical literature includes philosophical and theoretical papers that serve as background material. The nontechnical literature includes various archival data that can be used as primary data to support interviews and other primary data collection methods. The discussion mostly contributes to substantive theorizing rather than formal theorizing. Before his statement about avoiding a literature review before empirical work, Glaser stressed three conditions: first, the researchers should have sound field knowledge; second, the researcher should have some research experience; and third, literature reviews from unrelated fields (not directly contributing to theory generation) are welcome.

The three conditions involve literature in three areas: field literature, methodological literature, and background literature. To Glaser, the primary purpose of literature review from the three areas is to build research sensitivity rather than developing a "thesis chapter", and to turn knowledge into skills. What Glaser proposes is not against prior literature readings, but to keep a distance between prior knowledge and fieldwork, so that it is possible to maximize the outputs of social investigation beyond what is already in the field literature. GTM is adopting an inductive logic; it is not about verifying or confirming the existing theories, rather, it is to develop new theories. If findings from investigations through GTM are no 
different to other good inductive research methods, then the reason could be that researchers do not manage the tool, or the tool is not well designed, or both.

About the use of literature in formal grounded theorizing, Glaser stated $(1968$, p. 6): "the method of advancing from data to substantive theories to a grounded formal theory used here to generate a beginning formal theory of organizational careers has dictated the criteria for choosing and excerpting the articles from this volume". At the same time, he stated: "both substantive and formal theories must, we believe, be grounded in data" (Glaser, 1968, p. 4). The FGT developed in Organizational Career (Glaser, 1968) relies on literature entirely. However, in the original GTM design by Glaser and Strauss (1967), data and field literature are different, data are unanalyzed, while field literature is analyzed and processed. Glaser and Strauss claimed that there are three types of formal theorizing: grounded in systematic research, ungrounded, or a combination of both (grounded and ungrounded). The speculative or "ungrounded" theory, they argued, does not meet their criterion of "fit" and has limited capability in theory generation (Glaser \& Strauss, 1971, pp. 176-177). The FGT developed around organizational career by Glaser, according to their definition, is "ungrounded" and not "fit".

\section{Use of Ideal Types in Social Research}

Coser (1977, pp. 223-224) defined ideal type as "an analytical construct that serves the investigator as a measuring rod to ascertain similarities as well as deviations in concrete cases". Ideal types and concepts are fundamental to social discussion and investigation, and propositions about relationship are meaningless without them. Clarification of ideal types became fundamental for the development of new disciplines. If ideal types served to distinguish in Weber's time, in the context of social research today, ideal types should serve to merge and unify social concepts. One of the critical issues in social research now is the barriers imposed by terminologies used by scholars from different disciplines, which restricts in-depth interdisciplinary cooperation to advance theories. Ideal types are the first stream of literature contributing to the social theorizing process, as terminologies and partial classifications.

Weber also considers that ideal type is fundamental to comparative methods, as in the concept of "Name (名)" in classic Chinese philosophers such as Confucius and Mozi, and the process of raising ideal types and concepts is a process of comparing from the existing sets of concepts. Comparative analysis is the governing principle of GTM. Weber classifies ideal types into three categories according to the level of abstraction: ideal types associated with specific historical contexts; ideal types generalized through various historical and cultural contexts; and finally, ideal types relevant to human behavior (Coser, 1977). Confucius considered that the ideal type or concept development should be based on historical concepts and should make reality fit its original definition (正名论). In comparison, Mozi considered that ideal types and concepts should be based on reality. If ancient or classic terms conflict with reality, they should

be renamed to fit reality (取实予名). Weber's three kinds of ideal types combine the theory of rectification of Confucianism and Mohism. The first category of ideal type is more aligned with Confucianism; while the second and third categories both describe the empirical reality that is justified in Mohism. Glaser (1992, p. 38; 1978, p.74)'s theoretical coding discusses theoretical codes with similar functions to Weber's ideal types. The following modelling is a clarification of relevant ideal types.

To Weber, ideal types represent means that are not actually "exemplified in reality"; the clarification of ideal types is not towards a method or a tool of analysis, but to explain and refine the scientific concepts addressed by other social researchers to improve self-consciousness and reflexivity of research (MacRae, 1974, p. 65). To Weber, ideal types serve "the purpose of defining 'individual concrete patterns' and uniqueness and... as 'a mental construct for the measurement and systematic characterization of individuals' - that is significant in their uniqueness - context, such as Christianity, capitalism, etc."' (Kalberg, 1994, p. 84). Since the social reality to Weber is complex, infinite, and interrelated, preventing social reality from capturing full complexity, ideal types or concepts serve as a research tool rather than fully describing the nature of social reality. Ideal types served a purpose during Weber's time as concepts that describes sociological and economic phenomena. 
Weber considered that the scope of social economics consists of three categories of phenomena: economic phenomena, economically relevant phenomena; and economically conditioned phenomena, which makes the cultural meaning of "economic" around the material struggle for existence and scarcity. This model is very suitable to the analysis of historical cultural clusters in that the cultural meaning of "economic" is explicit in the phenomena. During analysis, the researcher should be aware of what are the economic phenomena that constitute "their primary cultural significance for us"; the economically relevant phenomena that "do not primarily interest us with respect to their economic significance" but whose consequences are of interest; and economically conditioned phenomena that do not primarily interest us with respect to their economic significance but are partially influenced by economic motives, such as fashion and artistic taste (Swedberg, 1998, pp. 192-193).

The categorization of social economic phenomena will help to separate value and cultural elements from economic motives. However, the analysis will be based on the empirical reality of the status of industrial development, and with notice that the industrial analysis is different from 100 years ago, with new cultural and economic ideal types and business structure, network, and interaction. The causal relationships in economic phenomena are more complicated, as there is a possibility that economically relevant phenomena and economically conditioned phenomena can change in cause-effect relationships. Scarcity, which is part of classical economics, cannot be the only economic driver; sustainability, social motives, and self-actualization could also be valid drivers for economic actions. It does not mean scarcity is no longer critical to economic analysis, but awareness of the multi-causality principle should not be limited to Weber's historical sociology and also economic sociology.

The discussion of ideal types is selective, not comprehensive. Terminologies shared by social researchers, such as terms about philosophies, social research methodologies, management and economics. The clarification of ideal types below will focus on the ideal types that are involved in the data analysis process which generate ties to specific context. Ideal types of cluster will be discussed, involving ideal types used by economic geographers and practitioners of cluster networking. Ideal types in porcelain production will be discussed and cross-compared with technical terms used in China. The identification of the three areas of ideal types aims to improve the quality and accuracy of data analysis in this paper.

\section{Suitability of Weberian Approach to Formal Grounded Theory}

Through the mist of ontological discussion in GTM, the conflicting ontological stances of Glaser (1967) and Strauss $(1990,2008)$ and even within the Glaserian and Straussian schools have caused ontological conflicts amongst GTM researchers (Borgström, 2012; Brown, 1995; Carcary, 2009; Gustavsson, 1998). Weber is actively examined and discussed still today (Albrow, 1990, Schroeder, 1992; Wu, 1993). "Does Weber still matter?" The answer is: "Weber matters by showing the degree to which many areas of historical and contemporary societies, and a number of methodological, conceptual and theoretical issues are still being considered from a Weberian and neo-Weberian perspective" (Chalcraft, Howell, Menendez, \& Vera, 2008, p. 3). The interest in Weber and how Weberian methodology will impact GTM development can attract more attention than GTM alone. This section discusses the possibility of a Weberian (neo-Kantian) approach in GTM in philosophy and methodology, and in social investigation.

Discussions and comparisons of GTM approaches conclude that neither the Glaserian nor the Straussian approach achieves philosophical consistency perceived by a group of GTM researchers. There is an opportunity to refine the theory to achieve better methodological coherence. The problem of inconsistencies within the GTM philosophy could be resolved by choosing a philosophical paradigm and sticking with it through a revision of the current GTM research procedure.

Max Weber, based on Kant, had a history of bridging social positivism and German idealism (social subjectivism) to lay a foundation for "objective validity" (Burrell \& Morgan, 1979, p. 229). Moreover, Weber was a German idealist from the school of neo-Kantianism and a key theorist in the sociological positivist paradigm that includes symbolic interactionism. Philosophically, Glaser's social positivism and Strauss's symbolic interactionism are both in the functionalist paradigm of sociology, like Weber himself 
(Burrell \& Morgan, 1979, pp. 22, 27, \& 69). Therefore, a Weberian approach to neo-Kantianism has the power to integrate the existing GTM approaches, as well as the interests of researchers from various perspectives to work with this newly positioned GTM - a Weberian (neo-Kantian) GTM is suitable from the philosophical perspective.

Weber is one of the founders of modern sociology alongside Marx and Durkheim, and his sociological methodologies, such as ideal types and comparative methods, upon which GTM design was originally built (Glaser \& Strauss, 1967), have become the dominant methodology in social research. This enables comparative research to happen in the idealist paradigm or beyond the social subjectivist paradigm. Objectivity and rationalization (Freund, 1968, pp. 17-18) are two areas that Weber develops to provide epistemological support for formal theorizing based on a substantive area of studies.

Hicks (1936, p. 135) stated that economists must look beyond economics for the discovery of long causal relationships, which they hope sociologists can take over but has rarely happened. Through successfully establishing theories in sociology, politics, economics, and cultural studies, Weber's comparative analysis is more broadly recognized and much ahead of Glaser and Strauss. They could not deny the sociological foundations laid by Weber in social theorizing based on empirical research that granted them the confidence in the "grounding of" their theorizing methodology in the field (Glaser \& Strauss, 1967, pp. 4, 10).

Glaser and Strauss also agreed that the development of FGT should be based on more than one substantive area (Glaser \& Strauss, 1967, pp. 81-82). The experience of Weber in the cross-disciplinary investigation of social events or actions can provide the theoretical foundation and contextual guidance needed to succeed in the emergence of FGT. The diversity of Weberian literature has led to the development of sub-areas of sociology, including political sociology ( $\mathrm{Wu}, 1993)$, historical sociology (Kalberg, 1994), cultural sociology (Schroeder, 1992), and economic sociology (Holton \& Turner, 1989; Swedberg, 1998; Chalcraft et al., 2008). The diversity of research interests is based on Weber's ideology of reality and considers that causal relationship analysis should be multiple, to explain social phenomena.

Weber developed ideal types such as rationalism, secularization, disenchantment, capitalism, modernism, economic sociology, ascetic Protestantism, social stratification, monopoly, bureaucracy, legal authority, economic history, objectivity vs. subjectivity, social behavior, social notion, historicism, comparative historical analysis, culture and religion (including that of China, India, and Judaism), social responsibility, Protestant ethics, and Calvinism, influencing the development of interpretivism, interpretive methods, phenomenological sociology, symbolic interactionism, anti-positivist, critical theory, a non-reductionist approach, critical interpretivism, phenomenology, linguistic pragmatics, cultural ethnography, ethnomethodology, and cultural anthropology (Albrow, 1990; Weber, 2012; Coser, 1977; Holton \& Turner, 1989; Kalberg, 1994; Schroeder, 1992; Swedberg, 1998; Burrell \& Morgan, 1979; Chowdhury, 2014). These ideal types provide concepts and typologies that are essential to advocate social theories and can become useful analytical tools in the interpretation of social phenomena. Ideal type is discussed as part of the use of literature in GTM in the following section.

There is not major conflict found between the Glaserian substantive GTM design and Weber's extensive writings in sociology, economics, and philosophy. Therefore, Weberian (Neo-Kantian) will become the underpinning philosophical approach in the formal GTM design of the paper.

\section{Weberian Approach among Existing Formal Grounded Theory}

Table 2 presents a systematic comparison of formal GTM approaches discussed in Section 3.3: the classic formal GTM by Glaser, Strauss and Corbin, and Charmaz; the emerging formal GTM by Kearney, Walsh, and Wallis; with the newly designed Weberian (Neo-Kantian) formal GTM approach. Weberian (Neo-Kantian) is based on classic (Glaserian) substantive GTM, engaging the Neo-Kantian mentality and Weber's epistemology and contributions to social knowledge.

This section serves the purpose of answering how the newly developed Weberian formal GTM approach similar and different from other formal GTM approaches. This section might also be suitable in Section 3.3.2 after the discussion of the formal GTM approaches; however, the Weberian formal GTM approach would be absent. 


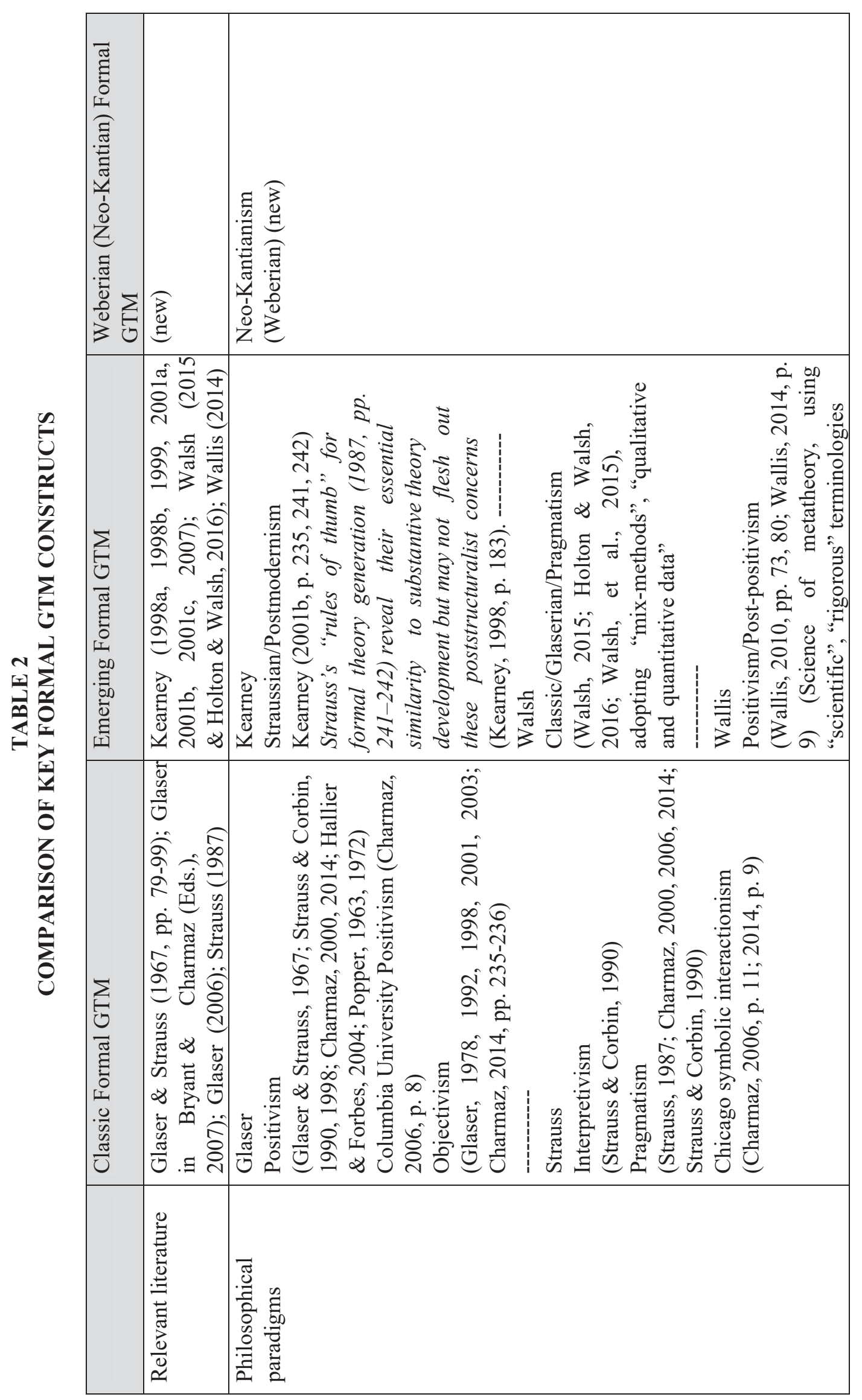

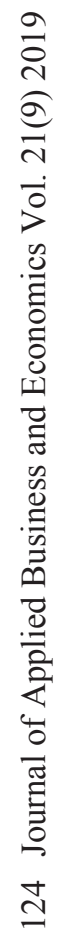




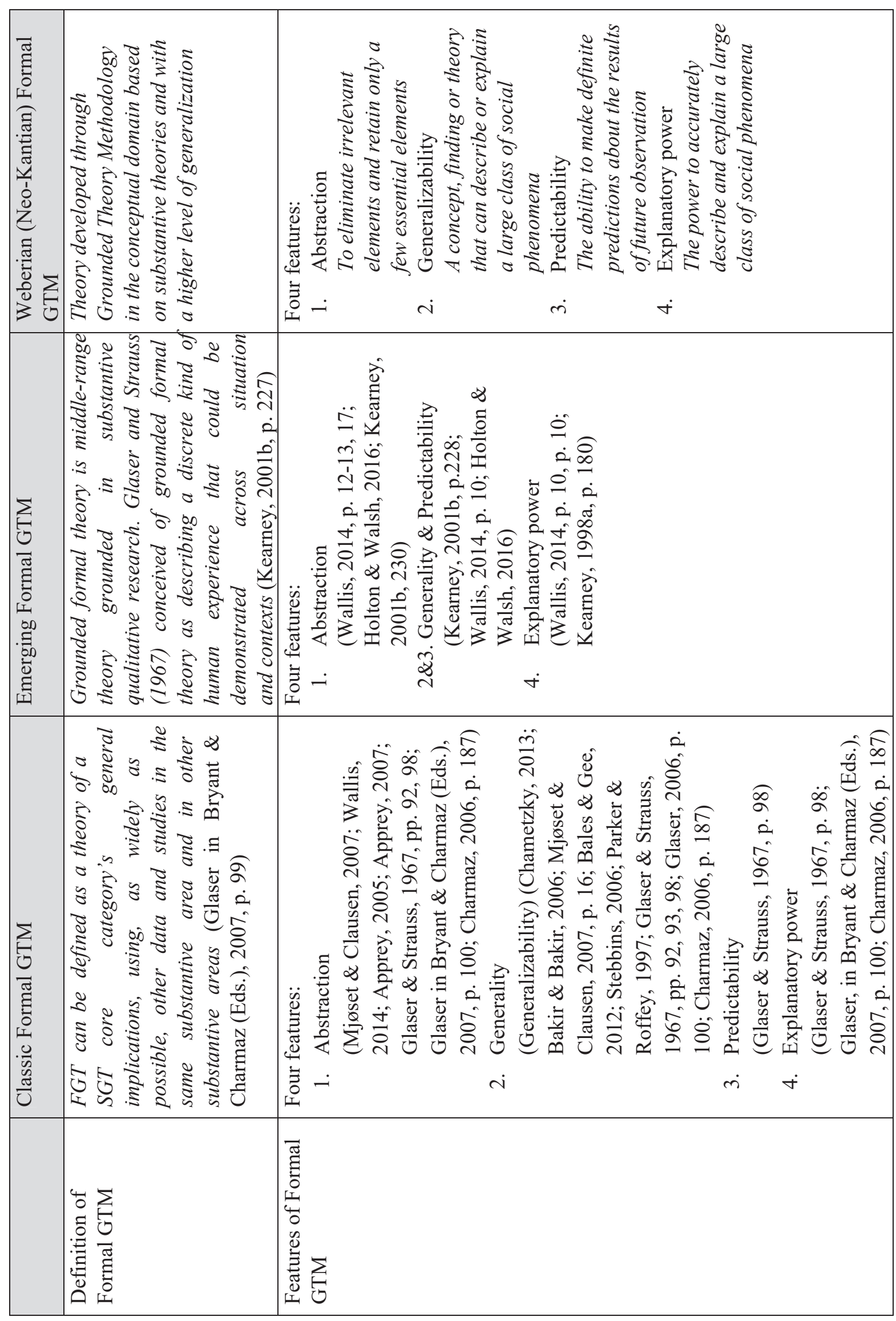




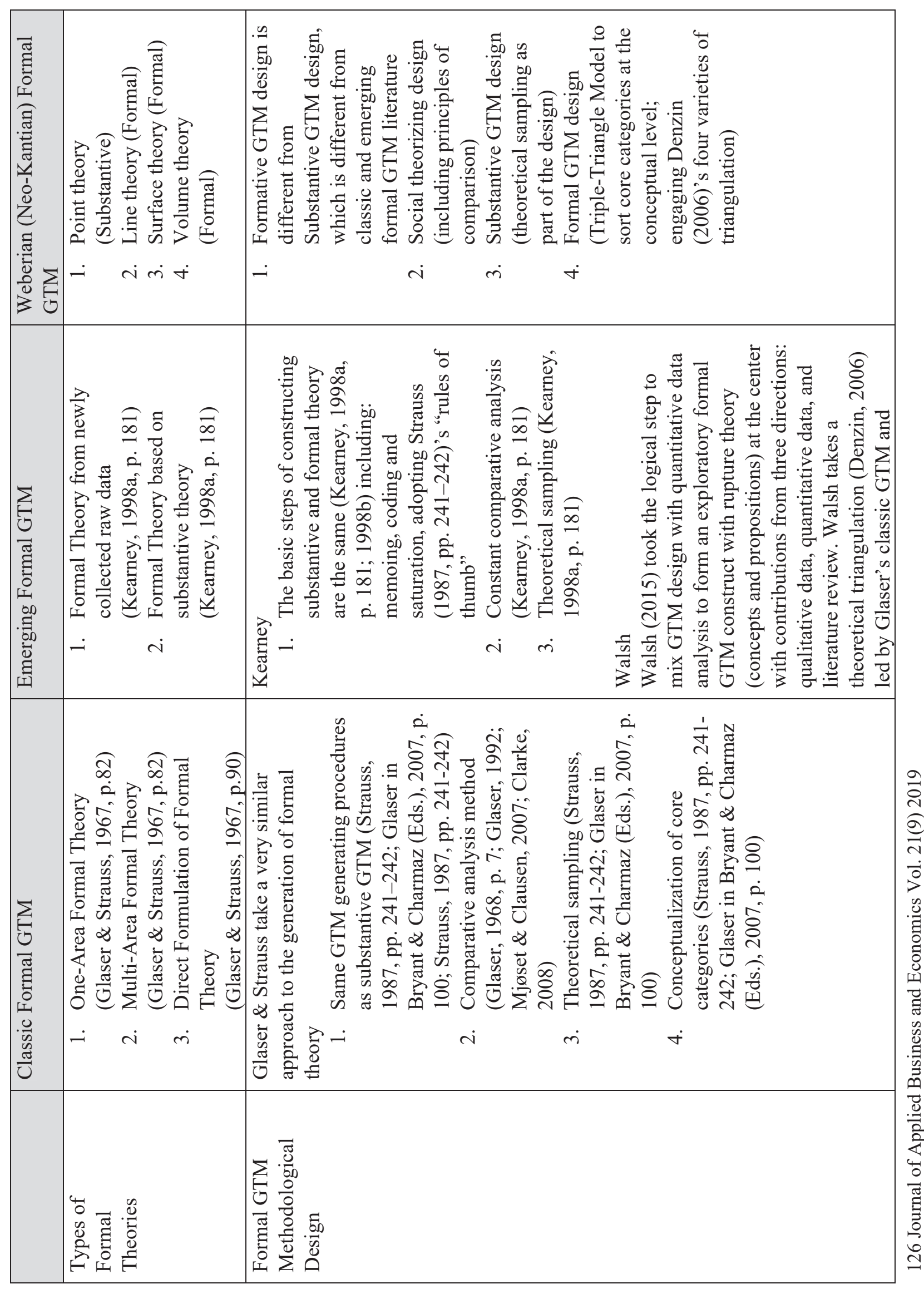




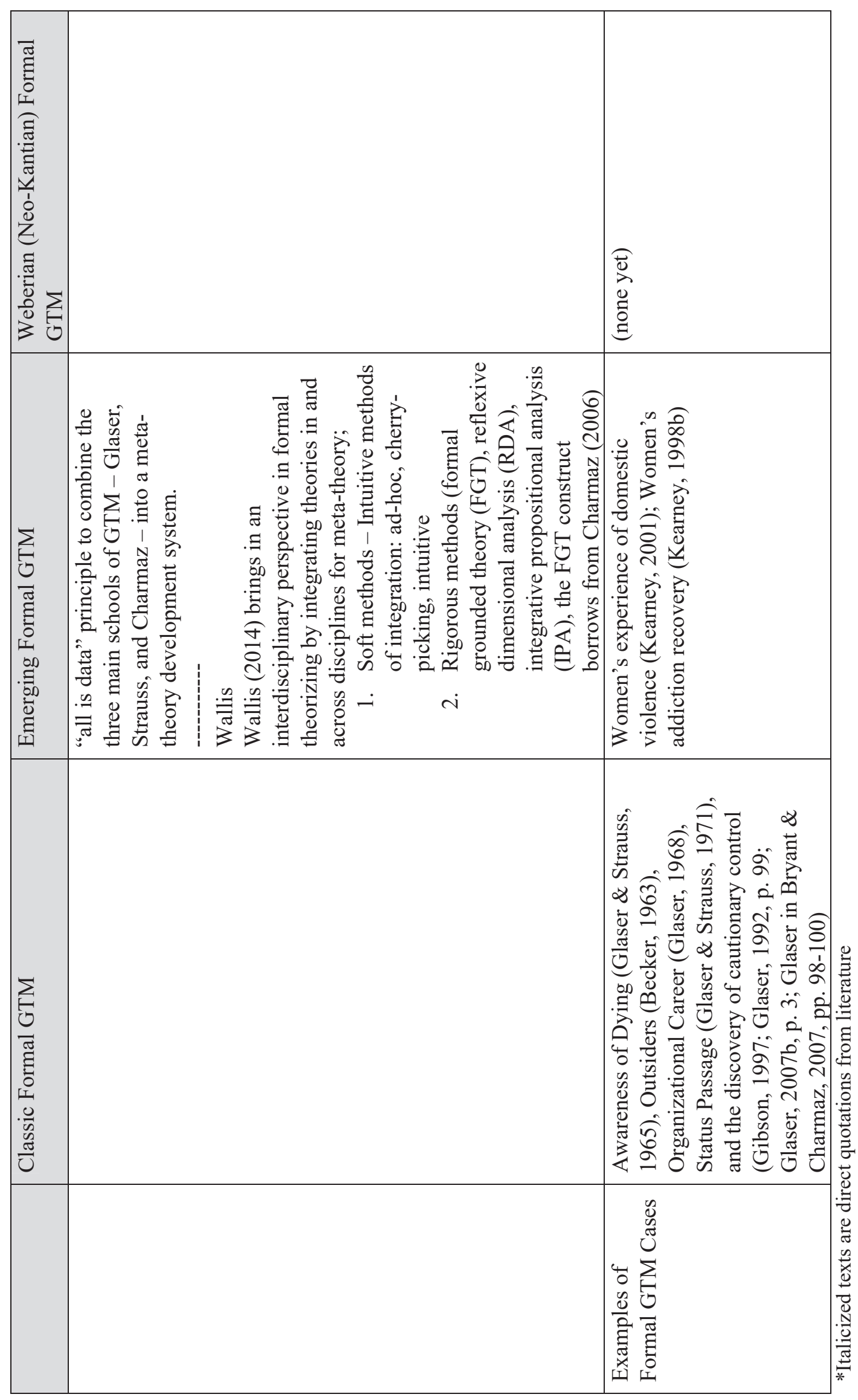

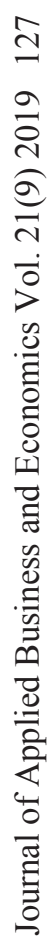


Table 2 above indicates the emerging formal GTM theorists' preference on the GTM schools, Kearney follows closely with Straussian approach, Walsh with Glaserian, and Wallis follows standard process based on Charmaz (2006). The features of formal GTM discussed earlier in Section 4.1.2.2 are shared across the three approaches. The typology of formal theories by Kearney relies heavily on the classification of Glaser and Strauss (1967); while Weberian formal GTM is based on a three-dimensional model in time, space and people dimensions. In terms of formal GTM design, the processes of classic GTM schools in substantive and formal GTM design are the same without limited explanation on how to achieve general application.

Among the emerging approaches, Kearney's formal GTM design follows the classic formal GTM design; she is the earliest theorist to claim to develop a formal GTM framework. Walsh and Wallis both integrate GTM as part of meta-theory construct. Walsh's meta-theory attempts to achieve theoretical triangulation among Glaserian, Straussian, and Charmaz's GTM, which is impossible to achieve by an individual researcher. Wallis, like Walsh, takes GTM as one of the rigorous methods as part of the metatheory construct without much contribution to how to achieve formal GTM. Apart from Kearney, Walsh and Wallis both take external methodological design governing the emergence of FGTs. They hold similar assumptions to the researcher: the differences between formal grounded theory and other middle range theories should share more similarities in comparison to theories developed at the substantive level. The constraint in formal GTM guidelines of classic GTM approaches thus provides the opportunity for other GTM researchers to make contributions to formal GTM.

\section{CONCLUSION}

In the substantive GTM section, the adaptation of GTM in business research and the schools of GTM are studied. Through investigation of research in GTM with data analysis software on the ProQuest database, management research has been discovered as the dominant group with a very high tendency to adopt software with GTM. With a significant proportion of management researchers conducting quantitative research, data analysis software, such as NVivo, aligns with their data analysis habits with quantitative research. In contrast, there is some degree of misunderstanding of GTM in management. GTM is taken for granted as a paradigm free to many GTM researchers without awareness of different GTM schools in research design.

Second, GTM schools are thoroughly examined and compared to gain a sound understanding of current developments in GTM in terms of philosophical approaches and research design. The three waves in the brief history of GTM are carefully studied. Extended literature discussion analyzed the philosophical approaches of the key contributors, namely Glaser, Strauss (and Corbin), and Charmaz. Perception and self-perception of the GTM schools in the Philosophy of Science construct are reviewed. The perception of GTM's philosophical approach is quite dynamic and not limited to what is claimed by Glaser and Strauss. Finally, research designs by Glaser and Strauss are compared in relation to the perception and self-perception of GTM design's philosophical approaches. There is a lack of consistency in the Glaser and Strauss approaches but not in that of Charmaz, who claims a constructivist GTM design.

Glaser and Strauss (1978) stated that there are two categories of grounded theories: substantive and formal grounded theories. The discussion of formal GTM covers the current development in formal GTM modelling as well as the possibility of a Weberian (neo-Kantian) approach to formal grounded theorizing. Under the current development, the nature of formal GTM, formal GTM contributed by Glaser, Strauss, and Charmaz, and other contributors in formal GTM design are discussed. The basic assumptions of FGT discussed in the literature include achieving generalizability, constructing with comparative analysis method, and reaching abstraction. For decades, Glaser claimed only five research projects that generated FGTs, including three of his own but the formal theories generated by Glaser do not "fit" with the description of FGT and proposed formal GTM construct. Contributions to formal GTM by Strauss, Corbin, and Charmaz are limited to theoretical discussions rather than the generation of FGTs. However, there are some great attempts by Kearney, Walsh, and Wallis. Kearney is one of the earliest formal GTM theorists. Walsh and Wallis both engage meta-theory design to GTM. Amongst the three, Walsh's design, 
which includes terminology clarification and traces GTM back to Paul Lazarsfeld and inductive quantitative methodology, is the best. The engagement of ideal types and discussion of social theorizing in this paper are inspired by Walsh. Difficulty in developing FGT and formal GTM construct is explicit in the writing of most formal GTM theorists.

The possibility of a Weberian (neo-Kantian) approach in formal GTM design is explored from two dimensions: the suitability of Weberian (neo-Kantian) approach in philosophy and methodology and how Weber is relevant in social research. It is apparent from the philosophical discussion of current GTM approaches that there is a lack of consistency in the schools of Glaser and Strauss. The neo-Kantian approach of Weber covers Glaser's social positivism and Strauss's symbolic interactionism. Moreover, Glaser and Strauss (1967) acknowledge that Weber contributes to their GTM design. The comparative method as the most critical component of GTM design is in great debt to Weber. Weber's scope of research has a broad coverage of social phenomena. His multi-disciplinary perspective in social investigation and multi-cultural comparison could provide the theoretical foundation for this research project and guidance to build cultural sensitivity. The relevance of Weber in philosophy, methodology, and social contexts is identified through the literature review. 


\section{REFERENCES}

Åge, L. J. (2011). Grounded Theory Methodology: Positivism, hermeneutics, and pragmatism. Qualitative Report, 16(6), 1599-1615.

Albrow, M. (1990). Max Weber's construction of social theory. London, UK: Macmillan Education.

Apprey, M. (2005). A formal grounded theory on the ethics of transfer in conflict resolution. Mind and Human Interaction, 14(2), 51-74.

Apprey, M. (2007). An attempt to create an ethic of transfer after conflict resolution in fractured communities: A modified formal grounded theory shaped by meta-ethnography. Psychotherapy and Politics International, 5(2), 130-152.

ATLAS.ti. (2014). About us. Retrieved from http://www.atlasti.com/aboutus.html

Bakir, A., \& Bakir, V. (2006). Unpacking complexity, pinning down the "elusiveness" of strategy: A grounded theory study in leisure and cultural organisations. Qualitative Research in Organizations and Management: An International Journal, 1(3), 152-172.

Bales, S., \& Gee, C. (2012). Critical interpretive synthesis for informing collection decisions. Collection Building, 32(2), 51-56.

Becker, H. (1963). Outsiders: Studies in sociology of deviance. New York, NY: The Free Press.

Borgström, B. (2012). Towards a methodology for studying supply chain practice. International Journal of Physical Distribution \& Logistics Management, 42(8/9), 843-862.

Brown, A. (1995), Managing understandings: politics, symbolism, niche marketing and the quest for legitimacy in IT implementation. Organization Studies, 16(6), 951-69.

Bryant, A. (2006). Thinking informatically: A new understanding of information, communication and technology. Lampeter, UK: Edwin Mellen.

Bryant, A., \& Charmaz, K. (Eds.) (2007). The SAGE handbook of grounded theory. London, UK: SAGE.

Burrell, G., \& Morgan, G. (1979). Sociological paradigms and organisational analysis: Elements of the sociology of corporate life. Aldershot, UK: Gower Publishing Company Limited.

Carcary, M. (2009). The research audit trial - Enhancing trustworthiness in qualitative inquiry. The Electronic Journal of Business Research Methods, 7(1), 11-24.

Chalcraft, D., Howell F., Menendez M. L., \& Vera, H. (Eds.) (2008). Max Weber matters: Interweaving past and present. Farnham, UK: Ashgate.

Chametzky, B. (2013). Generalisability and the theory of offsetting the affective filter. The Grounded Theory Review, 12(2), 1-9.

Charmaz, K. (2000). Grounded theory: Objectivist and constructivist methods. In N. Denzin \& Y. Lincoln (Eds.), Handbook of qualitative research (2nd ed., pp. 509-536). Thousand Oaks, CA: SAGE.

Charmaz, K. (2004). Premises, principles, and practices in qualitative research: Revisiting the foundation. Qualitative Health Research, 1(4), 976-993.

Charmaz, K. (2006). Constructing grounded theory: A practical guide through qualitative analysis. London, UK: SAGE.

Charmaz, K. (2008). Shifting the grounds: Constructivist grounded theory methods for the 21 st century. In J. Morse, P. N. Stern, J. Corbin, B. Bowers, K. Charmaz, \& A. E. Clarke (Eds.), Developing grounded theory. Walnut Creek, CA: Left Coast Press.

Charmaz, K. (2014). Constructing grounded theory (2nd ed.). London, UK: SAGE.

Charon, J. M. (2004). Symbolic interactionism (8th ed.). Upper Saddle River, NJ: Pearson Prentice Hall.

Chowdhury, M. F. (2014). Interpretivism in aiding our understanding of the contemporary social world. Open Journal of Philosophy, 4(03), 432.

Clarke, A. E. (2003). Situational analyses: Grounded theory mapping after the postmodern turn. Symbolic Interaction, 26(4), 553-576.

Clarke, A. E. (2005). Situational analysis: Grounded theory after the postmodern turn. Thousand Oaks, CA: SAGE.

130 Journal of Applied Business and Economics Vol. 21(9) 2019 
Clarke, A. E. (2007). Grounded theory: Conflicts, debates and situational analysis. In W. Outhwaite, \& S. P. Turner (Eds.), Handbook of social science methodology (pp. 838-885). Thousand Oaks, CA: SAGE.

Clarke, A. E. (2008). Celebrating Anselm Strauss and forty years of grounded theory. Studies in Symbolic Interaction, 32, 63-71.

Clarke, A. E., \& Star, S. L. (2007). The social worlds/arenas framework as a theory-methods package. In E. Hackett, O. Amsterdamska, M. Lynch \& J. Wacjman (Eds.), Handbook of science and technology studies (pp. 113-137). Cambridge, MA: MIT Press.

Corbin, J. M. (2009). Taking an analytic journey, developing grounded theory: The second generation. Walnut Creek, CA: Left Coast Press.

Corbin, J. M., \& Strauss, A. (1990). Grounded theory research: Procedures, canons, and evaluative criteria. Qualitative Sociology, 13(1), 3-21.

Corbin, J. M., \& Strauss, A. (2008). Basics of qualitative research (3rd ed.). Thousand Oaks, CA: SAGE.

Corbin, J. M., \& Strauss, A. (2015). Basics of qualitative research: Techniques and procedures for developing grounded theory. Thousand Oaks, CA: SAGE.

Coser, L. A. (1977). Masters of sociology thought: Ideas in historical and social context (2nd ed.). New York, NY: Harcourt Brace Jovanovich.

Creswell, J. W. (2007). Qualitative inquiry \& research design: Choosing among five approaches (2nd ed.). Thousand Oaks, CA: SAGE.

Denzin, N. K. (2006). Social methods: A sourcebook. New Brunswick, NJ: Transaction Publishers.

Denzin, N. K. (2007). Grounded theory and the politics of interpretation. In A. Bryant \& K. Charmaz (Eds.), The SAGE handbook of grounded theory (pp. 454-472). London, UK: SAGE.

Douglas, D. (2003). Inductive theory generation: A grounded approach to business inquiry. Electronic Journal of Business Research Methods, 2(1), 47-54.

Fernández, W. (2004). Using the Glaserian approach in grounded studies of emerging business practices. Electronic Journal of Business Research Methods, 2(2), 83-94.

Financial Times. (2012, February 22). 45 journals used in FT research rank. Financial Times. Retrieved from http://www.ft.com/intl/cms/s/2/3405a512-5cbb-11e1-8f1f-00144feabdc0.html\# axzz3c8MAxy2O.

Flick, U. (2018). Doing grounded theory (Book 8 of The SAGE qualitative research kit, 2nd ed.). London, UK: SAGE.

Freund, J. (1968). The sociology of Max Weber. Bristol, UK: Allen Lane \& Penguin Press.

Gibson, B. (1997). Dangerous dentaling: A grounded theory of HIV and dentistry (Doctoral dissertation). Queens University of Belfast, Belfast, UK.

Glaser, B. G. (1968). Organizational career: A sourcebook for theory. Chicago, IL: Aldine Publishing Company.

Glaser, B. G. (1978). Theoretical sensitivity: Advances in the methodology of grounded theory. Mill Valley, CA: Sociology Press.

Glaser, B. G. (1992). Basics of grounded theory analysis. Mill Valley, CA: Sociology Press.

Glaser, B. G. (1998). Doing grounded theory. Mill Valley, CA: Sociology Press.

Glaser, B. G. (1999). The future of grounded theory. Qualitative Health Research, 9(6), 836-845.

Glaser, B. G. (2001). The Grounded Theory perspective: Conceptualization contrasted with description. Mill Valley, CA: Sociology Press.

Glaser, B. G. (2002). Constructivist grounded theory? Forum: Qualitative Social Research, 3(3), Art.12.

Glaser, B. G. (2003). The Grounded Theory perspective II: Description's remodeling of grounded theory methodology. Mill Valley, CA: Sociology Press.

Glaser, B. G. (2006). Doing formal grounded theory: A proposal. Mill Valley, CA: Sociology Press.

Glaser, B. G. (2007a). Naturalist inquiry and grounded theory. Historical Social Research, Supplement, $19,114-132$.

Glaser, B. G. (2007b). Reading grounded theory: The value of exampling. The Grounded Theory Review, Nov, 1-8. 
Glaser, B. G. (2012). Constructivist grounded theory? The Grounded Theory Review, 11(1), 28-38.

Glaser, B. G., \& Strauss, A. L. (1965). Awareness of dying. Chicago, IL: Aldine Transaction.

Glaser, B. G., \& Strauss, A. L. (1967). The discovery of grounded theory: Strategies for qualitative research. Chicago, IL: Aldine de Gruyter.

Glaser, B. G., \& Strauss, A. L. (1971). Status passage. Chicago, IL: Aldine and Atherton, Inc.

Goulding, C. (1998). Grounded theory: the missing methodology on the interpretivist agenda. Qualitative Market Research: An International Journal, 1(1), 50-57.

Goulding, C. (1999). Grounded Theory: Some reflections on paradigm, procedures and misconceptions (WP006/99). Wolverhampton, UK: University of Wolverhampton.

Guba, E. G., \& Lincoln, Y. S. (1994). Competing paradigms in qualitative research. In N. K. Denzin \& Y. S. Lincoln (Eds). Handbook of qualitative research (pp. 105-117). Thousand Oaks, CA: SAGE.

Gustavsson, B. (1998). Metod: Grundad Teori for ekonomer - att navigera i empirins farvatten (Method: Grounded theory for economists - Navigating in empirical waters). Lund, Sweden: Academia Adacta.

Hallier, J., \& Forbes, T. (2004). In search of theory development in grounded investigations: Doctors' experiences of managing as an example of fitted and prospective theorizing. Journal of Management Studies, 41(8), 1379-1410.

Hallier, J., \& Forbes, T. (2004). In search of theory development in grounded investigations: Doctors' experiences of managing as an example of fitted and prospective theorizing. Journal of Management Studies, 41(8), 1379-1410.

Hicks, J. R. (1936). Economic theory and the social sciences: Their relations in theory and in teaching. London, UK: Le Play Press.

Holton, J. A., \& Walsh, I. (2016). Classic grounded theory: Applications with qualitative and quantitative data. Thousand Oaks, CA: SAGE.

Holton, R. J., \& Turner, B. S. (1989). Max Weber on economy and society. London, UK: Routledge.

Huber, J. (1973). Symbolic interaction as a pragmatic perspective: The bias of emergent theory. American Sociological Review, 38(2), 274-284.

Hunter, K., Hari, S., Egbu, C., \& Kelly, J. (2005). Grounded Theory: Its diversification and application through two examples from research studies on knowledge and value management. Electronic Journal of Business Research Methods, 3(1), 57-68.

Jones, R., \& Noble, G. (2007). Grounded theory and management research: A lack of integrity? Qualitative Research in Organisations and Management: An International Journal, 2(2), 84-103.

Kalberg, S. (1994). Max Weber's comparative-historical sociology. Oxford, UK: Blackwell Publishers.

Kearney, M. H. (1998a). Ready-to-wear: Discovering grounded formal theory. Research in Nursing and Health, 21(2), 179-186.

Kearney, M. H. (1998b). Truthful self-nurturing: A grounded formal theory of women's addiction recovery. Qualitative Health Research, 8(4), 495-512.

Kearney, M. H. (1999). Understanding women's recovery from illness and trauma. Thousand Oaks, CA: SAGE.

Kearney, M. H. (2007). From the sublime to the meticulous: The continuing evolution of grounded formal theory. In A. Bryant \& K. Charmaz (Eds.), The SAGE handbook of grounded theory (pp. 127150). London, UK: SAGE.

Kempster, S., \& Parry, K. W. (2011). Grounded theory and leadership research: A critical realist perspective. The Leadership Quarterly, 22(1): 106-120.

Kunchamboo, V., \& Lee, C. K. C. (2012). The meaning of nature and its implications on individual consumption behaviour. Advances in Consumer Research, 40, 395-402.

Locke, K. (2001). Grounded Theory in management research. London, UK: SAGE.

Locke, K. (2007). Rational control and irrational free-play: Dual-thinking modes as necessary tension in grounded theorising. In A. Bryant \& K. Charmaz (Eds.), The SAGE handbook of grounded theory (pp. 565-579). London, UK: SAGE.

132 Journal of Applied Business and Economics Vol. 21(9) 2019 
Loonam, J. (2014). Towards a Grounded Theory methodology: Reflections for management scholars, Irish Journal of Management, 33(1), 49-72.

Lowenberg, G. L. (1993). Interpretive research methodology: Broadening the dialogue. Advances in Nursing Science, 16(2), 57-69.

MacRae, D. G. (1974). Weber. London, UK: Fontana/Collins.

Malik, T. (2013). Positive effects of opinion-count on job satisfaction of team members in business enterprises. Journal of Communication Management, 17(1), 56-74.

McDermid, D. (2006). Pragmatism. Retrieved from http://www.iep.utm.edu/pragmati/

McKemmish, S. M., Burstein, F. V., Manaszewicz, R., Fisher, J. L., \& Evans, J. E. (2012). Inclusive research design: Unravelling the double hermeneutic spiral. Information, Communication \& Society, 15(7), 1106-35.

Merton, R. K. (1968). Social theory and social structure. New York, NY: The Free Press.

Mjøset, L., \& Clausen, T. H. (2007). An introduction to the comparison of capitalisms. Comparative Social Research, 24, 1-17.

Omar, A., Davis-Sramek, B., Fugate, B. S., \& Mentzer, J. T. (2012). Exploring the complex social processes of organisational change: Supply chain orientation from a manager's perspective. Journal of Business Logistics, 33(1), 4-19.

Parker, L. D., \& Roffey, B. H. (1997). Methodological themes: back to the drawing board: revisiting grounded theory and the everyday accountant's and manager's reality. Accounting, Auditing \& Accountability Journal, 10(2), 212-247.

Ponterotto, J. G. (2005). Qualitative research in counseling psychology: A primer on research paradigms and philosophy of science. Journal of Counseling Psychology, 52(2), 126-136.

Popper, K. (1963). Conjectures and refutations. London, UK: Routledge and Kegan Paul.

Popper, K. (1972). The logic of scientific discovery (3rd ed.). London, UK: Hutchinson.

Popper, K. R. (1992). The Logic of scientific discovery. London, UK: Routledge.

ProQuest. (2019). Search results. Retrieved from http://www.proquest.com

QSR International. (2014). Our history. Retrieved from http://www.qsrinternational.com/aboutqsr_history.aspx

Reiter, S., Stewart, G., \& Bruce, C. (2011). A strategy for delayed research method selection: Deciding between grounded theory and phenomenology. The Electronic Journal of Business Research Methods, 9(1), 35-46.

Reynolds, L. T., \& Herman-Kinney, N. J. (Eds.). (2003). Handbook of symbolic interactionism. Toronto, Canada: Rowman \& Littlefield.

Rodon, J., \& Pastor, J. A. (2007). Applying grounded theory to study the implementation of an interorganisational information system. Electronic Journal of Business Research Methods, 5(2), 71 83.

Schroeder, R. (1992). Max Weber and the sociology of culture. London, UK: SAGE.

Seldén, L. (2005). On grounded theory: With some malice. Journal of Documentation, 61(1), 114-129.

Shah, S. K., \& Corley, K. G. (2006). Building better theory by bridging the quantitative: Qualitative divide. Journal of Management Studies, 43(8), 1821-1835.

Stanford Encyclopedia of Philosophy. (2017). Abduction. Retrieved from http://plato.stanford.edu/entries/abduction

Star, S. L. (2007). Living grounded theory: Cognitive and emotional forms of pragmatism. In A. Bryant \& K. Charmaz (Eds.), The SAGE handbook of grounded theory (pp. 75-94). London, UK: SAGE.

Star, S. L., \& Strauss, A. (1999). Layers of silence, arenas of voice: The ecology of visible and invisible work. Computer supported cooperative work (CSCW), 8(1-2), 9-30.

Stebbins, R. A. (2006). Concatenated exploration aiding theoretic memory by planning well for the future. Journal of Contemporary Ethnography, 35(5), 483-494.

Stiles, J. A. (2003). A philosophical justification for a realist approach to strategic alliance research. Qualitative Market Research: An International Journal, 6(4), 263-271. 
Strauss, A. (1987). Qualitative analysis for social scientists. Cambridge, UK: Cambridge University Press.

Strauss, A., \& Corbin, J. (1990). Basics of qualitative research: Techniques and procedures for developing grounded theory. Newbury Park, CA: SAGE.

Strauss, A., \& Corbin, J. (1994). Grounded theory methodology: An overview. In N. Denzin \& Y. Lincoln (Eds.), Handbook of qualitative research (pp. 273-285). Newbury Park, CA: SAGE.

Strauss, A., \& Corbin, J. (1998). Basics of qualitative research: Techniques and procedures for developing grounded theory (2nd ed.). Thousand Oaks, CA: SAGE.

Strauss, A., \& Corbin, J. M. (Eds.) (1997). Grounded theory in practice. Thousand Oaks, CA: SAGE.

Strübing, J. (2007). Research as pragmatic problem-solving: The pragmatist roots of empiricallygrounded theorizing. In A. Bryant \& K. Charmaz (Eds.), The SAGE handbook of grounded theory (pp. 580-602). London, UK: SAGE.

Suddaby, R. (2006). From the editors: What grounded theory is not. Academy of Management Journal, 49(4), 633-642.

Swedberg, R. (1998). Max Weber and the idea of economic sociology. Princeton, NJ: Princeton University Press.

Tan, M. T. K., \& Hall, W. (2007). Beyond theoretical and methodological pluralism in interpretive IS research: The example of symbolic interactionist ethnography. Communications of the Association for Information Systems, 19(1), 26.

Wallis, S E. (2014). Existing and emerging methods for integrating theories within and between disciplines. Journal of Organisational Transformation \& Social Change, 11(1), 3-24.

Wallis, S. (2010). Toward a science of metatheory. Integral Review: A Transdisciplinary and Transcultural Journal for New Thought, Research, and Praxis, 6(3), 73-120.

Walsh, I. (2015). Using quantitative data in mixed - design grounded theory studies: An enhanced path to formal grounded theory in information systems. European Journal of Information Systems, 24(5), 531-557.

Walsh, I., Holton, J. A., Bailyn, L., Fernández, W., Levina, N., \& Glaser, B. (2015). What grounded theory is... A critically reflective conversation among scholars. Organizational Research Methods, 18(4), pp. 581-599.

Weber, M. (2012). Max Weber: Collected methodological writings (H. H. Bruun \& S. Whimster, Eds., H. H. Bruun, trans.), London, UK: Routledge.

Wu, G. (吴庚) (1993). Political theories and their philosophical foundation by Weber (韦伯的政治理论 及其哲学基础). Taipei, Taiwan: Lianjing (联经) [In Chinese].

Yeadon-Lee, A. (2013). Action learning: The possibility of differing hierarchies in learning sets. Action Learning: Research and Practice, 10(1), 39-53. 